\title{
The performance of the educator in the face of child violence in the Vitória de Santo Antão, Pernambuco, Brazil
}

\author{
Jéssica Gomes de Freitas ${ }^{1 *}$; Anierika Pereira dos Santos ${ }^{2}$; Soraia Lins de Arruda Costa ${ }^{3}$ \\ 1 University Center of Vitória de Santo Antão - UNIVISA. Nurse. \\ 2 University of Pernambuco - UPE. Student of the Master's course of the Graduate Program in Adolescent Medicine. \\ 3 University Center of Vitória de Santo Antão - UNIVISA. Professor of the Nursing course at the University Center of Vitória de Santo Antão \\ - UNIVISA. \\ E-mail adresses: jessicag_freitas@hotmail.com (Jéssica Gomes de Freitas), anierika.pereira@upe.br (Anierika Pereira dos Santos), \\ soraiafaint@hotmail.com (Soraia Lins de Arruda Costa) \\ ${ }^{*}$ Corresponding author
}

\section{To cite this article:}

Freitas, J.G.; Santos, A. P.; Costa, S.L.A. The performance of the educator in the face of child violence in the Vitória de Santo Antão, Pernambuco, Brazil. International Journal of Sciences. Vol. 1, No. 1, 2021, pp. 50-55. ISSN 2763-5392, DOI

Received: 03 28, 2021; Accepted: 03 30, 2021; Published: 04 08, 2021

\begin{abstract}
Violence can be classified as physical, psychological, verbal, sexual and/or neglect. The teacher's performance is important in identifying the student's behavioral changes. This study aimed to evaluate the ability of the education professional to analyze and identify possible aggressions suffered by children and adolescents. This is a descriptive analytical study with a quantitative-qualitative approach, carried out in public and private schools in the municipality of Vitória de Santo Antão, Pernambuco, Brazil. About the questioning of violence, $64.3 \%$ of teachers in the public network believe that it includes from physical to emotional aggression, already in the private school system, $40 \%$ stated that violence is the act of inflicting physical pain on the other. Regarding the attitude towards situations of violence, both schools stated that they denounced the school direction. Knowledge about violence is broad in both professionals, but there is a failure in decision-making. It is recommended better to guide public policies aimed at confronting violence.
\end{abstract}

Keywords: Early childhood education; Educator; Child violence.

\section{Introduction}

Violence has been present in the historical context since the beginning and is related to social, economic and cultural factors of a society. It is considered a serious public health problem according to the World Health Organization (WHO), not only because of the high mortality rates, but also because of the damage caused to the well-being and quality of life of people who suffer it in health and safety, not to mention the lifestyle of these individuals in society (MARTINS, 2015).

Violence is still a serious problem in terms of incidence and prevalence, epidemiological data reveal that the most reported types of violence are physical, sexual and the neglect of most victims is female. Regarding the aggressors, most are male, usually the father or stepfather, especially in situations of sexual abuse. As regards negligence, the mother is the main figure responsible for the mistreatment. (JUNIOR, 2015)

Studies show that domestic violence suffered by children and adolescents is responsible for numerous health damage, several sequelae can be identified, such as: mood disorders, anxiety, sleep problems, school problems, neurological disorders, depression, loss of quality of life in adulthood and possible reproduction of violence suffered (JUNIOR, 2015).

Every year, thousands of people die from violence, ranging from verbal aggression to physical aggression, injuries that can be fatal or not, self-inflicted, interpersonal or collective. Violence is one of the main causes of death among people aged 15 to 44 years, and when it is aimed at children and adolescents the repercussion is even greater, due to the damage that is most often irreparable, affecting the mental, physical and social development of this age group. (GARBIN, 2016).

Violence has some distinctions, domestic violence, which corresponds to individuals who live in the same residence, and intrafamily violence, which is uttered by a relative, not necessarily in the residence itself. It is essential to understand these concepts, since violence against children and adolescents should be analyzed within their entirety. (SILVA, 2011).

Child violence can be seen in a variety of ways, from physical abuse, which is any act that causes pain to the child; 
psychological and verbal aggressions, which are evidenced by the child's present contempt for the aggressor; sexual violence, which involves any act between parents, relatives or guardians of the minor, in order to sexually stimulate $\mathrm{him} / \mathrm{her}$; and negligence, which includes the omission of the provision of care to the physical or emotional needs of the minor (GARBIN, 2016).

In view of this, some legislations were created to protect and ensure children and adolescents, the main one is the Statute of Children and Adolescents (ECA), which guarantees rights and protection against any form of violence or oppression. The ECA ensures that the child (from 0 to 12 years) and the adolescent (12 - 18 years) are an absolute priority with guarantee of defense;

Law 13.010 that guarantees the right of the child to be educated without the use of physical punishment, cruel or degrading treatment in the family; and the Specialized Reference Center for Social Assistance (CREAS), which is a unit of care for families and individuals at personal or social risk resulting from abandonment, physical and/or psychological violence, sexual abuse, psychoactive drug use, street situations or child labor. Thus, cases of domestic violence against children and adolescents should be attended by CREAS and referred by the guardianship council, when there is a complaint or suspicion of victimization, for investigation and assistance in this modality of special social protection (JUNIOR, 2015).

The school suffers from the effects of external violence factors, which generate conflicts within the classroom, thus compromising the learning and interpersonal relationship of these individuals, the teacher's performance is important in child development, daily living in the classroom facilitates the observation of the behavior of children and adolescents, thus enabling a strategic action of the teacher in the identification of behavioral or physical changes of the student (SILVA ,2011).

The teacher's conception of violence is essential, because it has epidemic aspects in the life process that are still insufficiently known and therefore requires investigation, so it can be understood and identifiable. In this context, CREAS states that the school environment is the holder of the function of caring for and caring for children and adolescents, consequently it is expected that many complaints come from this institution, however, according to some researches, the average number of complaints made by schools is low when compared to sources such as hospitals, neighbors and relatives of victims (GARBIN, 2015).

Based on this assumption, this work aims to evaluate the ability of the education professional to analyze and identify possible aggressions suffered by children and adolescents in the municipality of Vitória de Santo Antão PE. Professionals who deal with children and adolescents, especially educators, should have notification and denunciation as allies to modify their work environment and avoid short- and long-term harm.

\section{Methodology}

This is a cross-sectional, descriptive and quantitativequalitative study, carried out in two schools located in the municipality of Vitória de Santo Antão - PE, being a municipal administrative school and one belonging to the private school system.

Vitória de Santo Antão is a municipality located geographically $55 \mathrm{~km}$ from the city of Recife, capital of the state of Pernambuco. An integral municipality of the Mesoregion of "Atlantic forest of Pernambuco", its population is estimated at 134,871 inhabitants occupying the tenth place among the most populous municipalities in the state.

The study in question was approved by the Research Ethics Committee of the University Center of Vitória de Santo Antão through the opinion: 3,356,487. Together with the State Department of Education. According to CNS resolution no. $446 / 12$, the participants were instructed about the study and agreeing with it by signing the Free and Informed Consent Form (TCLE).

The evaluation was performed through an adapted questionnaire (Appendix I) based on a study conducted by GARBIN (2015), applied in the form of an interview to all the educators who make up the sample. (Annex 1)

The research sample consisted of 80 educators from the public-school system and 16 educators who work in the private education network. The study population was organized based on the following criteria: Having higher education; have at least three years of experience in the area of training and work between the 6th year of elementary school and the 3rd year of high school. During the interview, participants were encouraged to report their knowledge and perceptions about child violence, their characteristics and possible attitudes towards such situations.

The questionnaire was applied in a school environment, the interviews lasted an average of 10 to 15 minutes each. The collection period took place between June and August of 2019. After collection, the data were organized in spreadsheets through the Microsoft Excel 2013 program and after this stage they underwent descriptive analysis in the same program, based on the absolute frequency of the results obtained. The results obtained were presented through tables for better visualization of them.

The analysis of the results of the interviews, which make up the qualitative part of the research, as mentioned was done using the content analysis method. First, the floating reading was made and then the exploration of the material of the interviews. With this, the existing categories in the discourse of the individuals were identified, always looking at the theoretical framework. The analysis path of this work takes as reference the work of Laurence Bardin, reference literature currently in content analysis.

\section{Results and Discussion}

The sample quantity of this study obtained as the final standard 15 teachers in the private network and 28 in the public network, since after analysis of inclusion and exclusion criteria, the amount of 80 teachers in the public network and 
16 teachers in the private network could not be reached. In both institutions it was not possible during the period of data collection to reach this maximum totality of teachers, where 4 teachers from the public network refused to participate and the rest were not available to perform the interview or were not present during data collection (48 in the public network and 1 in the private network).

Table 1. Sociodemographic characteristics of teachers of a public school and a private school in the municipality of Vitória de Santo Antão - PE

\begin{tabular}{cccccc}
\hline \multicolumn{2}{c}{ Public Profile } & \multicolumn{3}{c}{ Private Profile } \\
\hline Gender & $\mathrm{N}$ & $\%$ & Gender & $\mathrm{N}$ & $\%$ \\
\hline Female & 17 & $60,3 \%$ & Female & 11 & $73,3 \%$ \\
Male & 11 & $39,7 \%$ & Male & 4 & $26,7 \%$ \\
Total & 28 & $100 \%$ & Total & 15 & $100 \%$ \\
\hline Age Group & $\mathrm{N}$ & $\%$ & Age Group & $\mathrm{N}$ & $\%$ \\
\hline 20-35 Years & 7 & $25 \%$ & $20-35$ Years & 12 & $80 \%$ \\
\hline $36-45$ Years & 8 & $28,6 \%$ & $36-45$ Years & 3 & $20 \%$ \\
Old & & & Old & & \\
\hline 46-55 Years & 9 & $32,1 \%$ & $46-55$ Years & - & - \\
Old & & & Old & & \\
\hline $56-65$ Years & 4 & $14,3 \%$ & $56-65$ Years & - & - \\
\hline Total & 28 & $100 \%$ & Total & 15 & $100 \%$
\end{tabular}

\begin{tabular}{|c|c|c|c|c|c|}
\hline $\begin{array}{c}\text { Higher } \\
\text { Education }\end{array}$ & $\mathrm{N}$ & $\%$ & $\begin{array}{c}\text { Higher } \\
\text { Education }\end{array}$ & $\mathrm{N}$ & $\%$ \\
\hline Lic. Lyrics & 7 & $25 \%$ & Lic. Lyrics & 2 & $13,3 \%$ \\
\hline Lic. History & 4 & $14,3 \%$ & Lic. History & 4 & $26,6 \%$ \\
\hline $\begin{array}{c}\text { Lic. } \\
\text { Geography }\end{array}$ & 1 & $3,6 \%$ & $\begin{array}{c}\text { Lic. } \\
\text { Geography }\end{array}$ & 1 & $6,7 \%$ \\
\hline Music & 1 & $3,6 \%$ & Music & - & - \\
\hline $\begin{array}{c}\text { Lic. } \\
\text { Mathematics }\end{array}$ & 5 & $17,8 \%$ & $\begin{array}{c}\text { Lic. } \\
\text { Mathematics }\end{array}$ & 2 & $13,3 \%$ \\
\hline $\begin{array}{l}\text { Biological } \\
\text { Sciences }\end{array}$ & 3 & $10,7 \%$ & $\begin{array}{l}\text { Biological } \\
\text { Sciences }\end{array}$ & 3 & $20 \%$ \\
\hline Arts & 1 & $3,6 \%$ & Arts & - & - \\
\hline $\begin{array}{c}\text { Lic. } \\
\text { Chemistry }\end{array}$ & 2 & $7,1 \%$ & $\begin{array}{c}\text { Lic. } \\
\text { Chemistry }\end{array}$ & 1 & $6,7 \%$ \\
\hline English & 2 & $7,1 \%$ & English & - & - \\
\hline Pedagogy & 1 & $3,6 \%$ & Pedagogy & 1 & $6,7 \%$ \\
\hline Ed. Physical & 1 & $3,6 \%$ & Ed. Physical & 1 & $6,7 \%$ \\
\hline Total & 28 & $100 \%$ & Total & 15 & $100 \%$ \\
\hline
\end{tabular}

\begin{tabular}{|cccccc|}
\hline Graduate & $\mathrm{N}$ & $\%$ & Graduate & $\mathrm{N}$ & $\%$ \\
\hline Yes & 22 & $78,6 \%$ & Yes & 13 & $86,7 \%$ \\
\hline No & 6 & $21,4 \%$ & No & 2 & $13,3 \%$ \\
\hline Total & 28 & $100 \%$ & Total & 15 & $100 \%$ \\
\hline Acting Time & $\mathrm{N}$ & $\%$ & Acting Time & $\mathrm{N}$ & $\%$ \\
\hline 3-10 Years & 5 & $17,8 \%$ & $3-10$ Years & 11 & $73,4 \%$ \\
\hline $11-20$ Years & 10 & $35,7 \%$ & $11-20$ Years & 2 & $13,3 \%$ \\
\hline 21-30 Years & 10 & $35,7 \%$ & $21-30$ Years & 2 & $13,3 \%$ \\
\hline 31-40 Years & 3 & $10,7 \%$ & $31-40$ Years & - & - \\
\hline Total & 28 & $100 \%$ & Total & 15 & $100 \%$ \\
\hline
\end{tabular}

Source: Own elaboration, 2020

It was observed that there is a predominance of females in both institutions, $60.3 \%(\mathrm{n}=17)$ in the public network and $73.3 \%(n=11)$ in the private network. Regarding the age group, there was a divergence between the public network and the private network, where the age group between 36-45 years was predominant in the public network with $32.1 \%(\mathrm{n}=9)$ and a mean age of 43.7 years, already in the private network, with a predominance between $20-35$ years, equivalent to $80 \%(n=12)$, with a mean age of 30.8 years. When the level of education was evaluated, it was verified that all the teachers interviewed had higher education, especially public education in the course of letters with $25 \%(n=7)$ and in the private network the training in history equivalent to $26.6 \%(n=4)$, it was still possible to analyze that in the public network $78.6 \%(n=22)$ had graduate education, already in the private network $86.7 \%$ $(\mathrm{n}=13)$, with similar incidences.

It is important to highlight that the public profile for the private is quite different, since the bond of the public school teacher is through a public tender, generating greater stability and fixation of this professional in school, so it is possible to observe a greater age range of these, while the private network professionals are hired younger, also changing the view of this professional in the face of violence, with higher-updated curricular school graduation situpies, current social contextualization.

The school should be attentive and sensitive as to the severity of intrafamily violence and its consequences, it should develop methods of prevention and promotion of well-being, there should be guidance as to the measures to be taken to combat child violence at school, to build a bond between student and teacher based on trust and support, with this we perceive the need for quality academic training and permanent teaching of these teachers (GARBIN , 2015).

In what the time of operation is affirmed, it was emphasized in the public network between 11-30 years with $71.4 \%$ of professionals $(n=20)$, while in the private network the predominance was 3-10 years of performance equivalent to $73.4 \%$ of professionals $(n=11)$. This fact is given that public school teachers tend to be effective civil servants, which generates a greater stability of the execution time of the 
profession, and consequently a higher level of experience with various demands, including violence.

In the quantitative analysis, the data were decomposed into categories of analysis, which determined study variables, by the participating teacher by the following acronym, Q accompanied by a numeral referring to the question number in the questionnaire, followed by the part name for teachers of the private network and PÚB for public school teachers, with the numeral that determines the position of the participants in the research in a systematized order.

When evaluating the concept of violence given by teachers from the public and private network of Vitória de Santo Antão, the answers were verified and analyzed, and can classify them into three categories:

A) Global - physical, psychological, verbal, moral, sexual, abandonment, emotional framework: this category was mentioned in the speech of $64.3 \%(n=18)$ of public school teachers and by $26.6 \%(\mathrm{n}=4)$ of the private network, as verified in the following discourses: Q1púb1: "... verbal or nonverbal act that consists of antagonizing others..."

Q1púb2: "... intimidate, manipulate, use physical or psychological force..."

Q1part1: "... aggressively treat the other, physically, morally and emotionally..."

Q1part2: "... any kind of physical, verbal, psychological aggression..."

B) Social education: this category was present in 10.7\% $(n=3)$ of the reports of public school teachers and in $33.4 \%(\mathrm{n}=5)$ in the private network, as we can see in the following statements:

Q1púb3: "... treat others with respect..."

Q1púb4: "... lack of education, an educated society is less violent..."

Q1part3: "... any form of disrespect to the other..."

Q1part4: "... to overcome the limits that each individual delimits about himself without consent..."

C) Act of inflicting physical pain: this category was mentioned in $25 \%(\mathrm{n}=7)$ of the statements of teachers of the public network and $40 \%(n=6)$ among teachers of the private network, as we can see below:

Q1púb5: "... violent act against someone..."

Q1púb6: "... aggressively and unpermitted disruption of physical integrity..."

Q1part5: "... impose a physical force on the other..."

Q1part6: "... when the individual uses physical force..."

Among the categories presented, it was found that $64.3 \%$ $(\mathrm{n}=18)$ of public school teachers assessed that it encompasses from physical to emotional pain (global category), on the other hand, the private network presented $40 \%(\mathrm{n}=6)$ of teachers who agree that violence is only an act of inflicting physical pain on others.

Table 2. Analysis of the knowledge about violence of teachers of a public school and one of the private school of Vitória de Santo Antão - PE.

\section{Public Profile}

\section{Private Profile}

\begin{tabular}{cccccc}
\hline Gender & $\mathrm{N}$ & $\%$ & Gender & $\mathrm{N}$ & $\%$ \\
Female & 17 & $60,3 \%$ & Female & 11 & $73,3 \%$ \\
Male & 11 & $39,7 \%$ & Male & 4 & $26,7 \%$ \\
Total & 28 & $100 \%$ & Total & 15 & $100 \%$ \\
\hline
\end{tabular}

\begin{tabular}{cccccc} 
Age Group & N & $\%$ & Age Group & N & $\%$ \\
\hline 20-35 Years & 7 & $25 \%$ & $20-35$ Years & 12 & $80 \%$ \\
$\begin{array}{c}\text { 36-45 Years } \\
\text { Old }\end{array}$ & 8 & $28,6 \%$ & $\begin{array}{c}36-45 \text { Years } \\
\text { Old }\end{array}$ & 3 & $20 \%$ \\
$\begin{array}{c}\text { 46-55 Years } \\
\text { Old }\end{array}$ & 9 & $32,1 \%$ & $\begin{array}{c}46-55 \text { Years } \\
\text { Old }\end{array}$ & - & - \\
56-65 Years & 4 & $14,3 \%$ & $56-65$ Years & - & - \\
\hline Total & 28 & $100 \%$ & Total & 15 & $100 \%$ \\
\hline
\end{tabular}

\begin{tabular}{|c|c|c|c|c|c|}
\hline $\begin{array}{l}\text { Higher } \\
\text { Education }\end{array}$ & $\mathrm{N}$ & $\%$ & $\begin{array}{c}\text { Higher } \\
\text { Education }\end{array}$ & $\mathrm{N}$ & $\%$ \\
\hline Lic. Lyrics & 7 & $25 \%$ & Lic. Lyrics & 2 & $13,3 \%$ \\
\hline Lic. History & 4 & $14,3 \%$ & Lic. History & 4 & $26,6 \%$ \\
\hline $\begin{array}{l}\text { Lic. } \\
\text { Geography }\end{array}$ & 1 & $3,6 \%$ & $\begin{array}{l}\text { Lic. } \\
\text { Geography }\end{array}$ & 1 & $6,7 \%$ \\
\hline Music & 1 & $3,6 \%$ & Music & - & - \\
\hline $\begin{array}{c}\text { Lic. } \\
\text { Mathematics }\end{array}$ & 5 & $17,8 \%$ & $\begin{array}{c}\text { Lic. } \\
\text { Mathematics }\end{array}$ & 2 & $13,3 \%$ \\
\hline $\begin{array}{l}\text { Biological } \\
\text { Sciences }\end{array}$ & 3 & $10,7 \%$ & $\begin{array}{l}\text { Biological } \\
\text { Sciences }\end{array}$ & 3 & $20 \%$ \\
\hline Arts & 1 & $3,6 \%$ & Arts & - & - \\
\hline $\begin{array}{c}\text { Lic. } \\
\text { Chemistry }\end{array}$ & 2 & $7,1 \%$ & $\begin{array}{c}\text { Lic. } \\
\text { Chemistry }\end{array}$ & 1 & $6,7 \%$ \\
\hline English & 2 & $7,1 \%$ & English & - & - \\
\hline Pedagogy & 1 & $3,6 \%$ & Pedagogy & 1 & $6,7 \%$ \\
\hline Ed. Physical & 1 & $3,6 \%$ & Ed. Physical & 1 & $6,7 \%$ \\
\hline Total & 28 & $100 \%$ & Total & 15 & $100 \%$ \\
\hline
\end{tabular}

\begin{tabular}{|c|ccccc|}
\hline Graduate & N & $\%$ & Graduate & N & $\%$ \\
\hline Yes & 22 & $78,6 \%$ & Yes & 13 & $86,7 \%$ \\
\hline No & 6 & $21,4 \%$ & No & 2 & $13,3 \%$ \\
\hline Total & 28 & $100 \%$ & Total & 15 & $100 \%$ \\
\hline
\end{tabular}

\begin{tabular}{|cccccc}
\hline Acting Time & $\mathrm{N}$ & $\%$ & Acting Time & $\mathrm{N}$ & $\%$ \\
\hline 3-10 Years & 5 & $17,8 \%$ & $3-10$ Years & 11 & $73,4 \%$ \\
\hline 11-20 Years & 10 & $35,7 \%$ & $11-20$ Years & 2 & $13,3 \%$ \\
\hline 21-30 Years & 10 & $35,7 \%$ & $21-30$ Years & 2 & $13,3 \%$
\end{tabular}




\begin{tabular}{cccccc} 
31-40 Years & 3 & $10,7 \%$ & $31-40$ Years & - & - \\
Total & 28 & $100 \%$ & Total & 15 & $100 \%$ \\
\hline
\end{tabular}

Source: Own elaboration, 2020

Regarding the analysis of the classification of professionals related to violence, it was analyzed that in the public network $75 \%(n=21)$ of teachers considered sexual violence as more severe, resulting in a similar result to the private network with $73.3 \%(n=11)$. When it comes to violence considered mild, $35.7 \%(n=10)$ of public school teachers stated that no type of violence is considered mild, diverging from the private network that showed $53.3 \%(n=8)$ neglect and abandonment as mild violence. The data show differentiation in what was presented by Garbin et al. (2015), where all violence was considered serious, causing both physical and psychological damage to those who suffer. With regard to violence that occurs more frequently, 46.4\% $(n=13)$ psychological violence was identified by teachers in the public health system, while the private network considers verbal violence with $66.6 \%(n=10)$. In a study conducted in Caruaru - PE by Granville-Garcia and other authors (2006), shows neglect, followed by psychological, physical and sexual violence as the main violence. It is noteworthy that in all alternatives more than one choice were given, therefore, it was not reaching the equivalent of $100 \%$, except for the last question, where they were asked about the interference of violence in child growth and development, $75 \%(n=21)$ of public network professionals believe that yes, along with those of the private network with $100 \%(n=15)$ agreement.

It can be seen through these data that teachers have knowledge about the consequences that violence brings to the life of children and adolescents, since they stated that regardless of violence, there is interference in the growth and development of the same, which may cause deviation of character and conduct. The author also reports that today's victim is tomorrow's aggressor, in addition to psychological, emotional disorders related to sexual and reproductive health, in addition to illicit drug use, suicidal behavior, among others (NESELLO, 2014).

Regarding the signs presented by children and adolescents who were victims of violence, the data were represented by three categories:

A) Aggressiveness: this category was present in 39.3\% $(n=11)$ of the reports of teachers in the public network and in $26.7 \%(n=4)$ in the private network, as we can analyze in the following statements:

Q7púb26: "... he is aggressive wanting to take out in his colleagues the aggressions that he goes through at home..."

Q7púb11: "... becomes aggressive, has difficulty communicating..."

Q7part7: "... aggressiveness or social reclusive..."

Q7part14: "... aggressiveness, feel the need to belittle the other..."

B) Isolation and low school performance: this category was present in the discourse of $39.3 \%(n=11)$ of public school teachers and $46.6 \%(n=7)$ of the private network, as verified below
Q7púb23: "... does not interact with colleagues, has learning difficulties..."

Q7púb25: "... difficulty in interpersonal relationships, difficulty in learning, fear, shame..."

Q7part9: "... fear of the social, they are too quiet..."

Q7part2: "... crying for no apparent reason, fear of people, low school performance..."

C) Behavioral changes: this category was present in $21.4 \%(n=6)$ of the statements of professionals in the public network and $26.7 \%(n=4)$ in the private network, as we can see in the following statements:

Q7púb14: "... adverse attitudes and incompatible with the social level..."

Q7púb8: "... the behavior is usually reversed..."

Q7part11: "... emotional partner change of the victim..."

tremors, panic disturbances and persecution..."

Among the categories presented, it was found that $78.6 \%$ $(n=22)$ of public school teachers evaluated aggressiveness, isolation and low school performance as a common sign in children who suffered some type of violence, while in the private network presented $46.6 \%(n=7)$ of teachers who agree with isolation and low school performance. According to Garbin et al. (2016), the main sign observed was the presence of lice, highlighting the act of negligência,aggressiveness appears in second place and in smaller proportions he presented isolation and low school performance, and even untreated systemic diseases.

Regarding the factors that influence the practice of violence, $71 \%(\mathrm{n}=20)$ of public school teachers think it is directly linked to psychological, emotional and individual character disorders, together with the private network where $86.6 \%(n=13)$ of professionals opted for the same factor (According to table 3), agreeing in addition to what is presented by Garbin and other authors (2015), as a cause for the practice of violence.

Table 3. Perception of teachers of a public school and a private school in Vitória de Santo Antão about acts of violence, 2019.

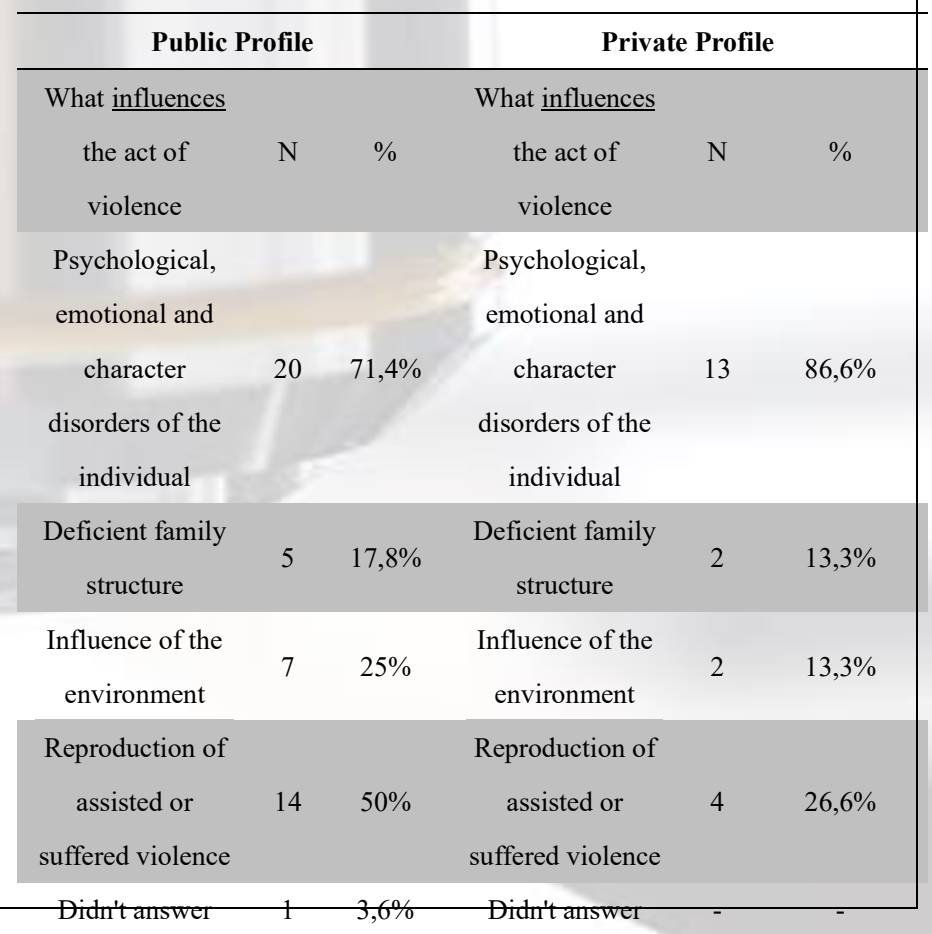


It is noticed that in both institutions most teachers have already identified some type of violence in their respective students, being possible to quantify $85.7 \%(n=24)$ in the public network, and $80 \%(\mathrm{n}=12)$ in the private network, among these, physical violence $46.4 \%(\mathrm{n}=13)$ and psychological violence $46.4 \%(n=13)$ were reported as the most identified violence in the public network, while bullying stood out in the private network with $33.3 \%(n=5)$. It is worth noting the divergence between institutions with regard to negligenciated and abandonment, in the private network no teacher identified this type of violence, while in the public network we can point out $21.4 \%(\mathrm{n}=6)$ of the professionals who identified such violence, given that this is justified by the socioeconomic profile of the student of the respective educational networks (According to table 4).

Table 4: The experience experienced with violence in the professional practice of teachers in the public and private network of Vitória de Santo Antão - PE.

\begin{tabular}{|c|c|c|c|c|c|}
\hline \multicolumn{3}{|c|}{ Public Profile } & \multicolumn{3}{|c|}{ Private Profile } \\
\hline $\begin{array}{l}\text { Have you } \\
\text { identified } \\
\text { any kind of } \\
\text { violence } \\
\text { suffered by } \\
\text { your } \\
\text { students? }\end{array}$ & $\mathrm{N}$ & $\%$ & $\begin{array}{c}\text { Have you } \\
\text { identified } \\
\text { any kind of } \\
\text { violence } \\
\text { suffered by } \\
\text { your } \\
\text { students? }\end{array}$ & $\mathrm{N}$ & $\%$ \\
\hline Yes & 24 & $85,7 \%$ & Yes & 12 & $80 \%$ \\
\hline No & 4 & $14,3 \%$ & No & 3 & $20 \%$ \\
\hline Total & 28 & $100 \%$ & Total: & 15 & $100 \%$ \\
\hline $\begin{array}{c}\text { What } \\
\text { violence did } \\
\text { you } \\
\text { identify? }\end{array}$ & $\mathrm{N}$ & $\%$ & $\begin{array}{c}\text { What } \\
\text { violence did } \\
\text { you } \\
\text { identify? }\end{array}$ & $\mathrm{N}$ & $\%$ \\
\hline $\begin{array}{l}\text { Physical } \\
\text { violence }\end{array}$ & 13 & $46,4 \%$ & $\begin{array}{l}\text { Physical } \\
\text { violence }\end{array}$ & 4 & $26,6 \%$ \\
\hline $\begin{array}{c}\text { Verbal } \\
\text { violence }\end{array}$ & 6 & $21,4 \%$ & $\begin{array}{c}\text { Verbal } \\
\text { violence }\end{array}$ & 4 & $26,6 \%$ \\
\hline Bullying & 7 & $25 \%$ & Bullying & 5 & $33,3 \%$ \\
\hline $\begin{array}{c}\text { Sexual } \\
\text { violence }\end{array}$ & 5 & $17,8 \%$ & $\begin{array}{c}\text { Sexual } \\
\text { violence }\end{array}$ & 1 & $6,6 \%$ \\
\hline $\begin{array}{l}\text { Psychologic } \\
\text { al violence }\end{array}$ & 13 & $46,4 \%$ & $\begin{array}{l}\text { Psychologic } \\
\text { al violence }\end{array}$ & 3 & $20 \%$ \\
\hline $\begin{array}{c}\text { Neglect/Aba } \\
\text { ndonment }\end{array}$ & 6 & $21,4 \%$ & $\begin{array}{c}\text { Neglect/Aba } \\
\text { ndonment }\end{array}$ & - & 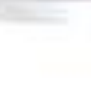 \\
\hline
\end{tabular}

$\begin{array}{lllll}\text { Would you } & \mathrm{N} & \% & \text { Would you } & \mathrm{N}\end{array}$

take action?

take action?

\begin{tabular}{|c|c|c|c|c|c|}
\hline Yes & 27 & $96,4 \%$ & Yes & 15 & $100 \%$ \\
\hline No & 1 & $3,6 \%$ & No & - & - \\
\hline Total & 28 & $100 \%$ & Total & 15 & $100 \%$ \\
\hline $\begin{array}{c}\text { What } \\
\text { attitude } \\
\text { would you } \\
\text { take? }\end{array}$ & $\mathrm{N}$ & $\%$ & $\begin{array}{c}\text { What } \\
\text { attitude } \\
\text { would you } \\
\text { take? }\end{array}$ & $\mathrm{N}$ & $\%$ \\
\hline Station & 7 & $25 \%$ & Station & 1 & $6,6 \%$ \\
\hline $\begin{array}{c}\text { Guardianshi } \\
\text { p Council }\end{array}$ & 9 & $32,1 \%$ & $\begin{array}{c}\text { Guardianshi } \\
\text { p Council }\end{array}$ & 6 & $40 \%$ \\
\hline $\begin{array}{c}\text { Dialogue } \\
\text { with family } \\
\text { members }\end{array}$ & 8 & $28,6 \%$ & $\begin{array}{l}\text { Dialogue } \\
\text { with family } \\
\text { members }\end{array}$ & 4 & $26,6 \%$ \\
\hline $\begin{array}{l}\text { School } \\
\text { direction }\end{array}$ & 18 & $64,3 \%$ & $\begin{array}{l}\text { School } \\
\text { direction }\end{array}$ & 11 & $73,3 \%$ \\
\hline $\begin{array}{c}\text { Have you } \\
\text { ever heard a } \\
\text { report of } \\
\text { violence } \\
\text { suffered by } \\
\text { a child or } \\
\text { adolescent? }\end{array}$ & $\mathrm{N}$ & $\%$ & $\begin{array}{c}\text { Have you } \\
\text { ever heard a } \\
\text { report of } \\
\text { violence } \\
\text { suffered by } \\
\text { a child or } \\
\text { adolescent? }\end{array}$ & $\mathrm{N}$ & $\%$ \\
\hline Yes & 18 & $64,3 \%$ & Yes & 10 & $66,7 \%$ \\
\hline No & 9 & $32,1 \%$ & No & 5 & $33,3 \%$ \\
\hline $\begin{array}{l}\text { Didn't } \\
\text { answer }\end{array}$ & 1 & $3,6 \%$ & $\begin{array}{l}\text { Didn't } \\
\text { answer }\end{array}$ & - & - \\
\hline Total & 28 & $100 \%$ & Total & 15 & $100 \%$ \\
\hline
\end{tabular}

Source: Own elaboration, 2020

When asked about the attitude they would take if they witnessed an act of violence, $96.4 \%(\mathrm{n}=27)$ of the public health professionals said they would interfere, $64.3 \%(n=18)$ of them would report the direction of the school, a similar data found in the private network, where $100 \%(\mathrm{n}=15)$ would interfere, and $73.3 \%(\mathrm{n}=11)$ would also report the direction of the school. Inrelation to what is presented by Garbin and other collaborators (2015), there is divergence, most professionals interfered through dialogue with the family member or would report it to the guardianship council. It is noted that there is no standardization regarding the attitude to be taken, which hinders a more intense action of these professionals, both in the notification of violence that occurred at school, as well as the perceived in school. (LIMA, 2015).

In a suspected or confirmed situation of violence, the professional must refer the child or adolescent to a ubs of 
residence, outpatient clinic or Caps, for psychological monitoring or to the social protection network of children victims of violence, or to the guardianship council, because they are responsible for the notification of these cases. In case of risk of violence, perform reception, promote preventive measures and refer to the UBS of residence, if the care occurs at the outpatient or hospital level. (BRAZIL, 2017).

In the public network, it was stated that $64.3 \%(\mathrm{n}=21)$ of teachers have heard reports of children and adolescents who have suffered some type of violence, while in the private network $66.7 \%$ have made the same statement. In some of the alternatives presented in Table 4, more than one choice was given, so some did not reach the final quantity of $100 \%$. The interviewees were asked about the reason that would lead them to interfere in an act of violence, for this question three categories were created:

A) Defense of theminor : this category was present in $64.3 \%(\mathrm{n}=18)$ of the reports of professionals from the public network and $60 \%(\mathrm{n}=9)$ in the private network, as can be analyzed below:

Q11púb13: "... to try to protect the child..."

Q11púb6: "... because the child is a being who does not know how to defend himself..."

Q11part15: "... the victim's incapacity..."

Q11part9: "... they have no way to defend themselves..."

B) Professional duty: $21.4 \%(n=6)$ of the discourses of public health professionals and $13.3 \%(\mathrm{n}=2)$ of the private network were present, as can be seen in the following excerpts:

Q11púb25: "... it is my duty as a citizen and educator..."

Q11púb15: "... because it is my duty as a teacher..."

Q11part8: "... because I'm an education professional, it's my duty..."

Q11part1: "... because it is my duty as a professional..."

C) Human duty: this category was present in $14.3 \%$ $(n=4)$ of public discourses and in $20 \%(n=3)$ in the private network, as we can see in the following statements:

Q11púb10: "... empathy and human duty..."

Q11púb18: "... is an ethical and human etator..."

Q11part14: "... because it does not agree with my ethical principles..."

Q11par11: "... for being human, to begin to cultivate respect in society..."

Among the categories presented, it was found that $64.3 \%$ $(n=18)$ of public school teachers evaluated that it was a defense of a defenseless (category defense of the minor), as well as the private network, which presented $60 \%(n=9)$ of teachers who agree with this category. According to Garbin and co-participants (2015), it is a human obligation and duty, moreover, the violence suffered can be reproduced or recidiva. Children and adolescents have fundamental rights as to any human being, direct protection, family, life and health, through the implementation of public social policies that allow birth and development in a healthy and harmonious way, in conditions worthy of existence, no child or adolescent will be subject to any form of negligence, discrimination, exploitation, violence, cruelty and or oppression, and if it occurs will be punished in the form of the law any attack, by action or omission, to these fundamental rights. (BRAZIL, 1990) .

\section{Conclusions}

The panorama presented by the following study shows that both teachers of the public-school system and those of the private network have extensive knowledge of the concepts of violence, its consequences in the lives of those who suffer it, and competence to identify them, however, there was a lack of guidance regarding the attitudes to be taken in situations of violence. It has protective measures, established by the Statute of children and adolescents, which is an important instrument in the fight against child violence, enabling the child protection and access to rights guaranteed by law.

Thus, it is recommended to better guide public policies aimed at coping with violence, the school should be attentive and sensitive as to the severity of intrafamily violence and its consequences, it should develop methods of prevention and promotion of well-being, allowing continuing education to professionals who deal directly with minors, thus having more guidance regarding the measures to be taken to combat child violence in schools.

\section{References}

[1] BIRTH, F. A.; DESLANDES, F. S. The construction of the Brazilian public agenda for confronting child-juvenile sexual violence. Physis Revista de Saúde Coletiva, Rio de Janeiro, 26 [4 ]: 1171-1191, 2016.

[2] FEDERAL, Government. Child and Adolescent Statute. Federal law, V.8,1990.

[3] GARBIN, S.A.C. et al. Knowledge and perception of early childhood education educators about violence. Plural Science Magazine. 2015;1(2):37-47.

[4] GARBIN, S.A.C. et al. Violence in the child population: epidemiological profile of abuses in the school environment. Plural Science Magazine. 2016; 2(2): 41-54.

[5] JUNIOR, P.A.A.; CASSEPP-BORGES, V.; SANTOS, J. G. Characterization of domestic violence against children and adolescents and interventionstrategies in a municipality in the State of Rio de Janeiro, Brazil. Cad. Saúde Colet., 2015, Rio de Janeiro, 23 (2): 124-131.

[6] JUSTINO, L.C. L. et al. SEXUAL VIOLENCE AGAINST ADOLESCENTS: notifications in the Tutelary Councils, Campo Grande, Mato Grosso do Sul, Brazil. Rev Gaúcha Enferm., Porto Alegre (RS) 2011 Dec;32(4):781-7.

[7] LEITE, T.J. et al. Coping with domestic violence against children and adolescents from the perspective of primary care nurses. Rev Gaúcha Enferm. 2016 Jun;37(2): e55796.

[8] MARTINS, G.B.C.; ALENCASTRO, S. C. L. Characteristics of violence suffered by school adolescents from a Brazilian capital. Rev. Eletr. Enf. [Internet]. 2015 Jul./Sep.; 17(3). 
[9] MEDEIROS, G.A.E.; BOEHS, E.A.; HEIDEMANN, B.S.T.I. The role of nurses and recommendations for the promotion of child health in Brazilian nursing publications. Rev Min Sick. 2013 Apr/Jun; 17(2): 462-467.

[10] NESELLO, F. et al. Characteristics of school violence in Brazil: a systematic review of quantitative studies. Rev. Bras. Matern Health. Infant., Recife, 14 (2): 119-136 Apr. / Jun., 2014.

[11] SILVIA, P.M. L.; FERRIANE, C. G.M.; SILVIA, I. A.M. Nursing action in the face of sexual violence against children and adolescents. Rev Bras Enferm, Brasilia 2011 Sep-Oct; 64(5): 919-24. 